Int. J. Electrochem. Sci., 14 (2019) 10248 - 10258

\title{
Zirconia/Poly(L-cysteine)/RGO-Modified Electrode for Sensing the CaMV 35S Gene Sequence
}

Keying Zhang, Na Zhang*, Hongyan Wang, Hongwei Shi, Qiao Liu, Cong Wang, Tao Geng, Guang Zhu

Anhui Key Laboratory of Spin Electron and Nanomaterials; School of Chemistry and ChemicalEngineering, Suzhou University, Suzhou, Anhui 234000, People's Republic of China

*E-mail: szxyzn@163.com

doi: $10.20964 / 2019.11 .12$

Received: 20 May 2019 / Accepted: 29 July 2019 / Published: 7 October 2019

Herein, a zirconia $\left(\mathrm{ZrO}_{2}\right) /$ poly$(\mathrm{L}$-cysteine)/reduced graphene oxide (RGO)-modified electrode was reported. $\mathrm{A} \mathrm{ZrO}_{2}$ film was electrodeposited onto the poly(L-cys)/RGO electrode surface. Probe DNA was modified on the electrode surface via the interaction of DNA phosphate groups and $\mathrm{ZrO}_{2}$. The electrochemical response changes of methylene blue were used as indicators for detecting target DNA. The performance of the biosensor was studied by electrochemical methods; methylene blue had an obvious change in its electrochemical signal when hybridized with completely matched target DNA compared with its signal when hybridized with mismatched target DNA. In addition, the biosensor had high sensitivity for completely matched target DNA, and the detection signals showed ideal linearity with a target DNA concentration range of $1.0 \times 10^{-13} \mathrm{~mol} / \mathrm{L}$ to $1.0 \times 10^{-9} \mathrm{~mol} / \mathrm{L}$. The detection limit was $2.6 \times 10^{-14} \mathrm{~mol} / \mathrm{L}(S / N=3)$. Experiments showed that the proposed biosensor had excellent reproducibility and stability and could be used to successfully assay the CaMV 35S gene sequence in human serum samples.

Keywords: CaMV 35S gene; Biosensor; Zirconia; RGO; Methylene blue

\section{FULL TEXT}

(C) 2019 The Authors. Published by ESG (www.electrochemsci.org). This article is an open access article distributed under the terms and conditions of the Creative Commons Attribution license (http://creativecommons.org/licenses/by/4.0/). 